\title{
PENENTUAN KANDUNGAN ANTIOKSIDAN DALAM RIMPANG KENCUR (Kaempferia galanga L.) YANG DIEKSTRAKSI DENGAN BANTUAN GELOMBANG ULTRASONIK
}

\author{
Indrawati $^{1}$, Fitria Suci Ariva ${ }^{1}$, Refilda $^{* 2}$ \\ ${ }^{1}$ Laboratorium Kimia Analisis Lingkungan, Jurusan Kimia FMIPA, Universitas Andalas \\ 2Laboratorium Kimia Analitik Terapan, Jurusan Kimia FMIPA, Universitas Andalas \\ e-mail: refilda_59@yahoo.com; refilda@sci.unand.ac.id
}

Diterima: 09 Oktober 2018 / Disetujui: 29 November 2018 / Dipublikasi online: 15 Desember 2018 DOI: $10.22437 /$ chp.v3i2.5769

\begin{abstract}
Kaempferia galanga L. rhizome is used a traditional medicine and as seasoning. Kaempferia galanga L. rhizome has many bioactivies beneficial to antioxidant. Extraction of antioxidant by maceration method takes a long time and the extraction process is not perfect so ultrasonic assisted extraction (UAE) are used to accelerate the extraction process. The propose of the research is to extract antioxidant from Kaempferia galanga L. rhizome by UAE and to determinate the antioxidant content by 1,1-diphenyl-2-picrilhydrazyl (DPPH) method. The optimum conditions for extraction were $20 \mathrm{~mL}$ methanol as the solvent, the weight of sample $1.5 \mathrm{~g}$, and extraction time 60 minutes. The total antioxidant content from Kaempferia galanga L. rhizome extraction by maceration and UAE were $0.6688 \pm 0.02$ and $0.8126 \pm 0.02 \mathrm{mg} / \mathrm{g}$ $D W$. This study also validated the method of determining the total antioxidant content extracted with ultrasonic. The results of the method validation obtained linearity $(r)=-0.9984$, LoD value $=0.0283 \mathrm{mg} / \mathrm{L}$, LoQ value $=0.0947 \mathrm{mg} / \mathrm{L}$, precision $(S D R=1.97 \%$ and HORRAT $=$ 0.96) and percent recovery $103.21 \%$. Based on the method validation value, it can be said that the determination of the total antioxidant content in the Kaempferia galanga L. rhizome extracted with the help of UAE can be applied.
\end{abstract}

Keywords: Kaempferia galanga L. rhizome, antioxidant, ultrasonic, method validation

\begin{abstract}
ABSTRAK
Rimpang kencur banyak digunakan sebagai ramuan obat tradisonal dan bumbu dalam masakan. Rimpang kencur mengandung senyawa bioaktif yang dapat dimanfaatkan sebagai antioksidan. Ekstraksi antioksidan dengan metode maserasi memerlukan waktu yang lama dan proses pengekstraksian kurang sempurna sehingga digunakan bantuan gelombang ultrasonik untuk mempercepat proses ekstraksi. Penelitian ini bertujuan untuk mengetahui kondisi optimum pengekstraksian antioksidan dalam rimpang menggunakan bantuan gelombang ultrasonik dan menentukan kandungan antioksidan total menggunakan metode DPPH. Kondisi optimum pengekstraksian adalah menggunakan $20 \mathrm{~mL}$ pelarut metanol, berat sampel 1,5 gram, dan waktu pengekstraksian 60 menit. Kandungan antioksidan total dalam rimpang kencur yang diekstraksi dengan maserasi dan bantuan gelombang ultrasonik adalah 0,6688 $\pm 0,02$ dan 0,8126 $\pm 0,02 \mathrm{mg} / \mathrm{g} \mathrm{DW}$. Penelitian ini juga dilakukan validasi metode penentuan kandungan antioksidan total yang diekstraksi dengan bantuan gelombang ultrasonik. Hasil validasi metode yang didapatkan linearitas $(r)=-0,9984$, nilai $L o D=0,0283 \mathrm{mg} / \mathrm{L}$, nilai $L o Q=0,0942 \mathrm{mg} / \mathrm{L}$, presisi $(S D R=1,97 \%$ dan HORRAT $=0,96)$ dan perolehan kembali yang didapatkan 103,21\%. Berdasarkan nilai validasi metode dapat dikatakan bahwa penentuan kandungan antioksidan total dalam rimpang kencur yang diekstraksi dengan bantuan gelombang ultrasonik dapat diterapkan.
\end{abstract}

Kata Kunci: Kencur, antioksidan, gelobang ultrasonik, validasi metode

\section{PENDAHULUAN}

Kencur (Kaempferia galanga L.) merupakan tanaman yang banyak dibudidayakan di Indonesia, India, Malaysia dan Cina. Di Indonesia tanaman ini banyak terdapat didaerah Jawa Tengah, Jawa Tengah, Kalimantan Selatan, Jawa Timur, Jawa Barat, Yogyakarta dan 
Sumatera Barat. Bagian dari tenaman kencur yang banyak digunakan adalah akar yang terdapat didalam tanah yang disebut dengan rimpang kencur atau rizoma. Rimpang kencur digunakan sebagai ramuan obat tradisional dan bumbu dalam masakan (Salim dan Muradi, 2012) Penelitian yang pernah dilakukan oleh Hayati, et al 2015 diperoleh informasi kencur mengadung senyawa flavonoid, polifenol, alkaloid dan tanin. Dimana flavonoid dan polifenol merupakan kelompok senyawa metabolit sekunder yang berperan sebagai antioksidan.

Antioksidan adalah senyawa yang mampu mengahambat terjadinya reaksi oksidasi. Reaksi oksidasi terbentuk karena banyak radikal bebas dalam tubuh. Serangan dari radikal bebas dapat menyebabkan terjadi kerusakan sel atau jaringan, berbagai penyakit hingga (Wallinger, 2015). Tubuh manusia memproduksi antioksidan tetapi jumlahnya sering tidak cukup untuk menetralkan radikal bebas yang masuk kedalam tubuh. Oleh sebab itu dibutuhkan tambahan antioksidan untuk mencegah terjadinya pembentukan radikal bebas dalam tubuh. Antioksidan berdasarkan sumbernya terbagi menjadi dua yaitu antioksidan sintetik dan antioksidan alami. Antioksidan sintetik berasal dari hasil sintentis senyawa kimia sedangkan antioksidan alami berasal dari hasil ekstraksi bahan alam tumbuhan (Bundit, 2016) seperti rimpang kencur yang digunakan pada penelitian ini.

Ekstraksi antioksidan umumnya menggunakan metode maserasi, dimana sampel direndam dengan pelarut dalam waktu tertentu. Pengekstraksi dengan metode maserasi memiliki kekurangan diantaranya waktu pengerjaan yang lama dan proses pengekstraksian yang kurang sempurna (Xu, et al, 2015). Sehingga pada penelitian ini dilakukan proses ekstraksi menggunakan bantuan gelombang ultrasonik. Dimana ekstraksi dengan bantuan gelombang ultrasonik pengerjaannya hampir sama dengan maserasi, perbedaanya adalah ultrasonik memanfaatkan gelombang ultrasonik untuk mempercepat proses ekstraksi. Gelombang ultrasonik memiliki frekuensi diatas $20 \mathrm{kHz}$ (Mathialagan, 2017).

Kondisi optimum ekstraksi antioksidan rimpang kencur menggunakan bantuan gelombang ultrasonik berdasarkan pengaruh jenis pelarut, berat sampel dalam volume pelarut yang sama dan waktu pengekstraksian dipelajari, hasilnya dibandingkan dengan metode maserasi. Kandungan antioksida total yang dihitung sebagai asam askorbat ditentukan dengan metode 1,1 difenil-2-pikrilhidrazil (DPPH). Metode DPPH adalah metode yang didasarkan pada kemampuan antioksidan untuk mengikat radikal DPPH. DPPH memberikan serapan maksimum pada panjang gelombang $517 \mathrm{~nm}$ dengan warna larutan ungu. Semakin banyak antioksidan dalam sampel maka warna larutan DPPH akan memudar sampai berwarna kuning. Metode DPPH dipilih karena hasil pengamatanya mudah diamati, waktu analisisnya cepat, dan hasil yang didapat akurat (Dragovic, et al 2010).

Validasi metode penentuan kandungan antioksidan yang diekstraksi dengan menggunkan bantuan gelombang ultrasonik juga dilakukan. Validasi metode dilakukan 
untuk memastikan bahwa metode yang digunkan mempu menghasilkan data yang valid. Validasi metode dilakukan dengan beberapa uji parameter statistik seperti linearitas, LoD dan LoQ, presisi, dan akurasi.

\section{METODOLOGI PENELITIAN}

Alat

Alat yang digunakan pada penelitian ini adalah neraca analitik Kern ABJ, kaca arloji, botol kaca gelap, ultrasonik RK-510 (frekuensi $35 \mathrm{kHz}$ ), oven, desikator, spetrofotometer UV-Vis (PD 303S Spectrophotometer) dan peralatan gelas.

\section{Bahan}

Bahan-bahan yang digunakan pada penelitian ini adalah rimpang kencur (Kaempferia galanga L.), methanol 96\% teknis, air destilasi yang dibuat di laboratorium Jurusan Kimia FMIPA Unand, etil asetat 96\% (teknis), n-heksana 96\% (teknis), asam askorbat p.a (Merck), 1,1-difenil-2-pikrihidrazil (DPPH) p.a.(Sigma Aldrich), kertas saring, aluminium foil.

\section{Prosedur Penelitian}

Persiapan Sampel

Rimpang kencur (Kaempferia galanga L.) diambil di daerah Lubuk Basung, Kabupaten Agam. Rimpang kencur segar ditimbang $\pm 2 \mathrm{~kg}$ dibersihkan dengan air untuk menghilangkan tanah yang menempel, lalu dipotong kecil-kecil, dikering anginkan, setelah itu dihaluskan. Sampel ini digunakan untuk semua perlakuan.

Penentuan Kadar Air

Kadar air ditentukan dengan metode gravimetri, dimana cawan porselen dioven selama \pm 1 jam pada suhu $105{ }^{\circ} \mathrm{C}$, kemudian diletakkan dalam desikator selama \pm 30 menit dan ditimbang. Sampel $( \pm 2,0 \mathrm{~g})$ dimasukkan ke dalam cawan tersebut, kemudian dioven selama \pm 3 jam pada suhu $105^{\circ} \mathrm{C}$, setelah itu dimasukkan kedalam desikator selama \pm 30 menit, kemudian dioven dan didesikator lagi sampai didapatkan berat konstan. Dihitung persentase kadar airnya (Standar AOAC, 2012).

Pembuatan Kurva Kalibrasi Larutan Standar Asam Askorbat

Dibuat variasi konsentrasi larutan standar asam askorbat 0, 2, 4, 6, 8, 10 dan 12 $\mathrm{mg} / \mathrm{L}$ dari larutan induk $100 \mathrm{mg} / \mathrm{L}$. Dipipet masing-masing $2 \mathrm{~mL}$ larutan standar asam askorbat, dimasukkan ke dalam botol vial. Ditambahkan $3 \mathrm{~mL}$ larutan DPPH 0,1 mM, kemudian didiamkan selama 30 menit. Absorban diukur pada panjang gelombang 517 nm. Hasil pengukuran dibuat kurva kalibrasi yang menunjukkan hubungan antara konsentrasi dan absorban.

\section{Penentuan Kondisi Optimum Pengekstrasian Antioksidan Dengan Menggunakan Bantuan Gelombang Ultrasonik}

Pengaruh Jenis Pelarut

Sampel kering angin sebanyak 2,0 g ditambahkan dengan $20 \mathrm{~mL}$ akuades dan dilakukan ultrasonik selama 15 menit. Ekstrak yang dihasilkan diencerkan 10 kali, 
kemudian dipipet $2 \mathrm{~mL}$ dan ditambahkan $3 \mathrm{~mL}$ DPPH 0,1 mM, setelah itu didiamkan selama 30 menit. Absorban diukur pada panjang gelombang $517 \mathrm{~nm}$. Dihitung kandungan antioksidan menggunakan persamaan regresi dari kurva kalibrasi larutan standar asam askorbat. Percobaan dilakukan sebanyak 3 kali pengulangan. Hal yang sama dilakukan untuk pelarut etanol, etil asetat, dan n-heksana.

Pengaruh Berat Sampel dengan Volume Pelarut yang Sama

Sampel seberat 1,$0 ; 1,5 ; 2,5$; dan 3,5 g masing-masing ditambahkan dengan $20 \mathrm{~mL}$ metanol dan dilakukan ultrasonik selama 15 menit. Ekstrak yang dihasilkan diencerkan 10 kali kemudian dipipet $2 \mathrm{~mL}$ dan ditambahkan $3 \mathrm{~mL}$ DPPH $0,1 \mathrm{mM}$, setelah itu didiamkan selama 30 menit. Absorban diukur pada panjang gelombang $517 \mathrm{~nm}$. Dihitung kandungan antioksidan menggunakan persamaan regresi dari kurva kalibrasi larutan standar asam askorbat. Percobaan dilakukan sebanyak 3 kali pengulangan.

Pengaruh Waktu Pengekstraksian

Sampel kering angin ditimbang 1,5 g, ditambahkan $20 \mathrm{~mL}$ metanol dan dilakukan ultrasonik selama 15, 30, 45, 60, 75, dan 90 menit. Ekstrak yang dihasilkan diencerkan 10 kali kemudian dipipet $2 \mathrm{~mL}$ dan ditambahkan $3 \mathrm{~mL}$ DPPH 0,1 , setelah itu didiamkan selama 30 menit. Absorban diukur pada panjang gelombang $517 \mathrm{~nm}$. Dihitung kandungan antioksidan menggunakan persamaan regresi dari kurva kalibrasi larutan standar asam askorbat. Percobaan dilakukan sebanyak 3 kali pengulangan.

Pengaruh Metode Pengekstraksian

Sampel kering angin 1,5 g dimasukkan kedalam 2 buah botol vial $100 \mathrm{~mL}$. Botol vial pertama ditmbahkan $20 \mathrm{~mL}$ metanol dan direndam selama 60 menit. Botol vial kedua ditambahkan $20 \mathrm{~mL}$ metanol dan diultrasonik selama 60 menit. Masing-masing ekstrak yang diperoleh diencerkan 10 kali kemudian dipipet $2 \mathrm{~mL}$ dan ditambahkan $3 \mathrm{~mL}$ DPPH 0,1 $\mathrm{mM}$, setelah itu didiamkan selama 30 menit. Absorban diukur pada panjang gelombang $517 \mathrm{~nm}$. Dihitung kandungan antioksidan menggunakan persamaan regresi dari kurva kalibrasi larutan standar asam askorbat. Percobaan dilakukan sebanyak 3 kali pengulangan. Hal yang sama juga dilakukan untuk rimpang kencur segar.

\section{Validasi Metode}

\section{Linearitas}

Linearitas diperoleh dari kurva kalibrasi larutan standar asam askorbat dengan memplotkan konsentrasi dengan absorban. Sebagai parameter hubungan linear digunakan koefisien korelasi pada analisis regresi linear $\mathrm{y}=\mathrm{ax}+\mathrm{b}$.

LoD dan LoQ

LoD dihitung dari 3 kali simpangan baku kurva kalibrasi larutan standar asam askorbat dibagi slope persamaan garis linear

$$
L o D=\frac{3 S}{B}
$$


LoQ dihitung dari 10 kali simpangan baku kurva kalibrasi larutan standar asam askorbat dibagi slope persamaan garis linear.

$$
L o D=\frac{10 S}{B}
$$

Presisi

Presisi suatu metode ditentukan dengan melihat standar deviasi relatif. Data yang didapat dilakukan uji data terpencil (outlier) terlebih dahulu. Nilai SDR dihitung dengan membagi nilai standar deviasi yang diperoleh dengan nilai rata-rata.

Dari nilai SDR yang diperoleh dibandingkan dengan nilai Horwitz. Dimana nilai Horwitz merupakan SDR yang diperkirakan melalui persamaan rumus $\left(\mathrm{H}=2^{1-0,5 \log C}\right)$. Kriteria presisi suatu metode ditetapkan berdasarkan nilai rasio Horwitz (HORRAT).

\section{Akurasi}

Parameter dari penentuan akurasi yaitu berdasarkan persen perolehan kembali (recovery). Persen perolehan kembali metode analisa dinyatakan dalam rumus:

[]-

Dimana: [sampel + standar] $=$ ekstrak sampel yang sudah diencerkan 10 kali dipipet $2 \mathrm{~mL}$ kedalam botol vial gelap, ditambahkan $2 \mathrm{~mL}$ larutan asam askorbat $4 \mathrm{mg} / \mathrm{L}$ dan $3 \mathrm{~mL}$ larutan DPPH 0,1 mM kemudian didiamkan selama 30 menit. Diukur absorban pada panjang gelombang $517 \mathrm{~nm}$. [sampel] = ekstrak sampel yang sudah diencerkan 10 kali dipipet $2 \mathrm{~mL}$ kedalam botol vial gelap, ditambahkan $3 \mathrm{~mL}$ larutan DPPH 0,1 mM kemudian didiamkan selama 30 menit. Diukur absorban pada panjang gelombang $517 \mathrm{~nm}$.

\section{PEMBAHASAN}

\section{Analisa Kadar Air}

Kadar air dari rimpang kencur ditentukan untuk mengetahui berat kering btul kring dari rimpang kencur. Kadar air pada sampel ditentukan dengan metode gravimetri, dimana sampel dipanaskan pada suhu $105{ }^{\circ} \mathrm{C}$ untuk menguapkan molekul air yang terdapat pada sampel. Kadar air dari rimpang kencur segar didapatkan adalah $81,49 \%$. Setelah rimpang kencur dikering anginkan selama 14 hari kadar air dalam sampel menjadi 20,52\%. Rimpang kencur dikering anginkan pada suhu ruang berfungsi untuk mengurangi kadar air dan menghindari rusaknya senyawa aktif yang terdapat dalam sampel (Suryani, et.al 2015). Selain itu agar antioksidan yang didapatkan lebih maksimal karena sampel yang digunakan jumlahnya lebih banyak dibandingkan dengan rimpang kencur segar.

\section{Penentuan Kondisi Optimum Pengekstrasian Antioksidan Dengan Menggunakan Bantuan Gelombang Ultrasonik}




\section{Pengaruh Jenis Pelarut}

Sampel rimpang kencur diekstrak dengan menggunakan empat pelarut (akuades, metanol, etil asetat, dan n-heksana) yang berbeda tingkat kepolarannya. Pengaruh pelarut yang digunakan terhadap kandungan antioksidan dalam rimpang kencur dapat dilihat pada Gambar 1. Kandungan antioksidan tertinggi dalam rimpang kencur didapatkan dengan menggunakan pelarut metanol adalah 0,4387 $\pm 0,02 \mathrm{mg} / \mathrm{g}$ DW. Hal ini disebabkan karena kencur memili kandungan senyawa flavonoid dan fenolik yang larut dalam pelarut polar. Diman senyawa fenolik dan flavonoid berperan sebagai antioksidan.

Akuades memiliki kepolaran yang lebih tinggi dibandingkan dengan metanol, namun kandungan antioksidan tertinggi didapatkan pada pelarut metanol. Hal ini disebabkan senyawa bioaktif yang terdapat dalam rimpang kenciur larut baiik dalam metanol. Selain itu pelarut metanol merupakan pelarut universal yang dapat melarutkan senyawa polar dan semi polar. Penelitian yang dilakukan oleh Elfalleh, et al (2012) mengenai kandungan fenolik total dan aktivitas antioksidan dari kulit, biji, daun, dan bunga delima yang diekstrak dengan pelarut akuades dan metanol didaptkan hasil aktivitas antioksidan tertinggi pada pelarut metanol.

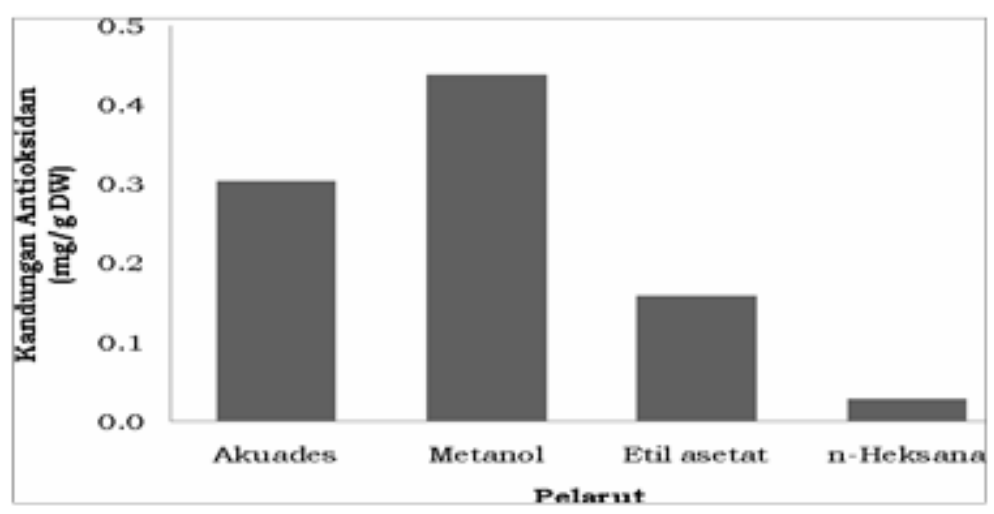

Gambar 1. Pengaruh jenis pelarut terhadap kandungan antioksidan ekstrak kencur. Pengaruh Berat Sampel dengan Volume Pelarut yang Sama

Dari empat variasi berat sampel $(1 ; 1,5 ; 2,5$; dan 3)g yang diekstrak dalam $20 \mathrm{~mL}$ pelarut metanol, didapatkan kandungan antioksidan tertinggi pada berat sampel 1,5 g adalah $0,5997 \pm 0,03 \mathrm{mg} / \mathrm{g} \mathrm{DW}$. Pengaruh variasi berat sampel dengan $20 \mathrm{~mL}$ pelarut metanol dapat dilihat pada Gambar 2.

Dari Gambar 2 dapat diamati berat sampel mempengaruh kandungan antioksidan yang dihasilkan, dimana kandungan antioksidan maksimal didapat pada berat 1,5 g dengan voleme pelarut $20 \mathrm{~mL}$. Hal ini dikarenakan perbandingan jumlah sampel rimpang kencur dengan jumlah pelarut yang digunakan sudah cukup untuk mendapatkan kandungan antioksidan yang maksimum, sehingga pada penambahan berat yang lebih besar dengan jumlah pelarut yang sama tidak dapat mengekstrak antioksidan dengan maksimal. Penelitian yang dilakukan oleh Petigny, (2013) mengenai ekstraksi daun boldo menggunakan ultrasonik dengan variasi berat sampel/pelarut $(1 \%, 4 \%, 6 \%, 10 \%$ dan 
$20 \%$ ) didapatkan ekstrak tertinggi pada berat sampel/pelarut $6 \%$. Hal ini disebabkan perbandingan berat sampel dengan pelarut yang digunakan sudah cukup untuk menghasilkan kandungan antioksidan yang maksimal.

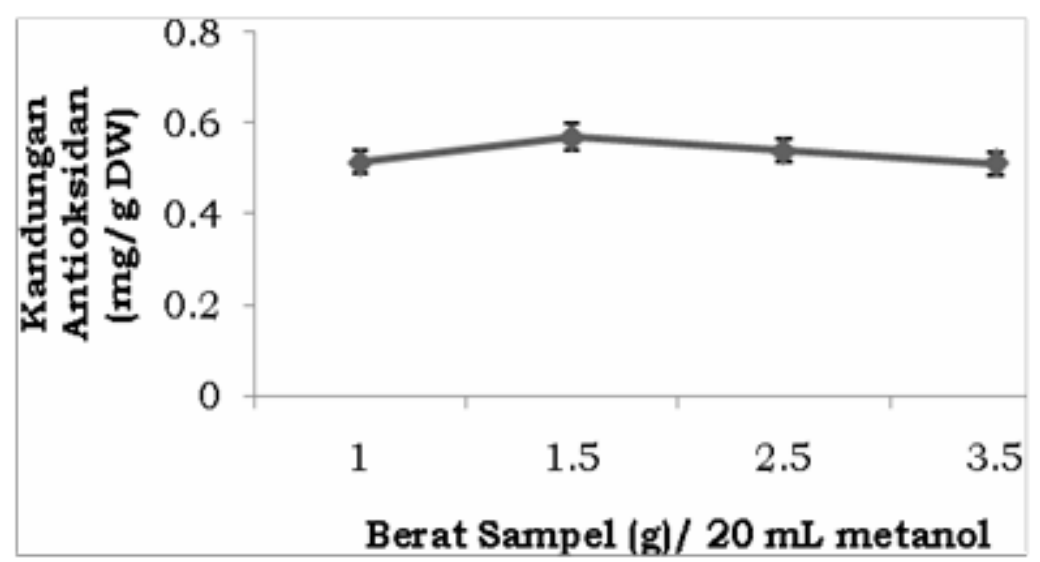

Gambar 2. Pengaruh berat sampel yang diekstrak dengan $20 \mathrm{~mL}$ metanol selama 15 menit terhadap kandungan antioksidan dalam rimpang kencur.

\section{Pengaruh Waktu Pengekstraksian}

Pengaruh waktu pengekstraksian terhadap kandungan antioksidan yang didapatkan dalam sampel rimpang kencur dapat dilihat pada Gambar 3. Semakin lama watu yang digunakan maka kandungan antioksidan yang didapatkan akan semakin banyak. Hal ini disebabkan karena interaksi antara sampel dengan pelarut semakin besar sehingga hasilnya akan bertambah sampai titik jenuh larutan (Muhammad, 2017). Kandungan antioksidan tertinggi didapatkan pada menit ke-90 sebesar 0,7289 $\pm 0,02 \mathrm{mg} / \mathrm{g}$ DW.

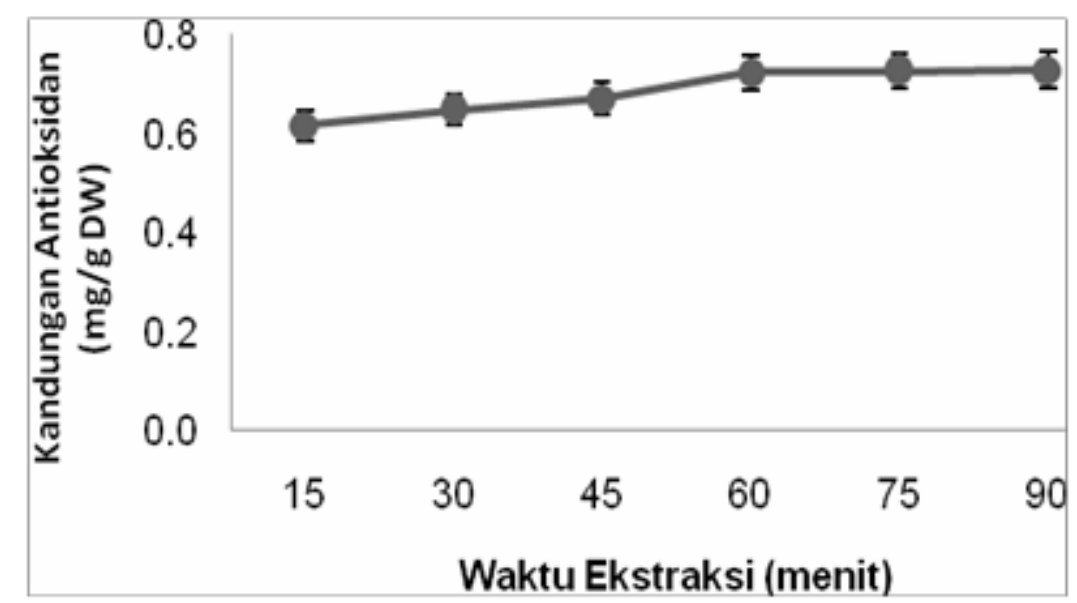

Gambar 3. Pengaruh waktu ekstraksi terhadap kandungan antioksidan dalam rimpang kencur.

Pada menit ke-60 kandungan antioksidan yang didapatkan mengalami kenaikan yang tidak signifikan, hal ini dikarenakan pada menit ke-60 pelarut yang digunakan untuk ekstraksi sudah mulai jenuh, sehingga pada menit ke-75 dan 90 kandungan antioksidan yang didapatkan hampir sama. Kandungan antioksidan yang didapatkan 
pada menit ke-60 adalah 0,7240 $\pm 0,03 \mathrm{mg} / \mathrm{g}$ DW. Penelitian yang dilakukan oleh Hadiyanto et. al (2014) tentang ekstraksi antioksidan dari kulit kentang menggunakan ultrasonik dengan variasi waktu ekstraksi yang digunakan 30, 45, dan 60 menit, didapatkan hasil ekstraksi tertinggi pada menit ke 60 sebesar 72,83 $\pm 0,65 \mathrm{mg} / \mathrm{g}$.

\section{Pengaruh Metode Ekstraksi}

Pada penelitian ini dilakukan perbandingan ekstraksi dengan maserasi dan bantuan gelombang ultrasonik, dimana sampel yang digunakan adalah sampel segar dan kering. Hasil kandungan antioksidan yang didapat dari kedua metode yang digunakan dapat dilihat pada Gambar 4.

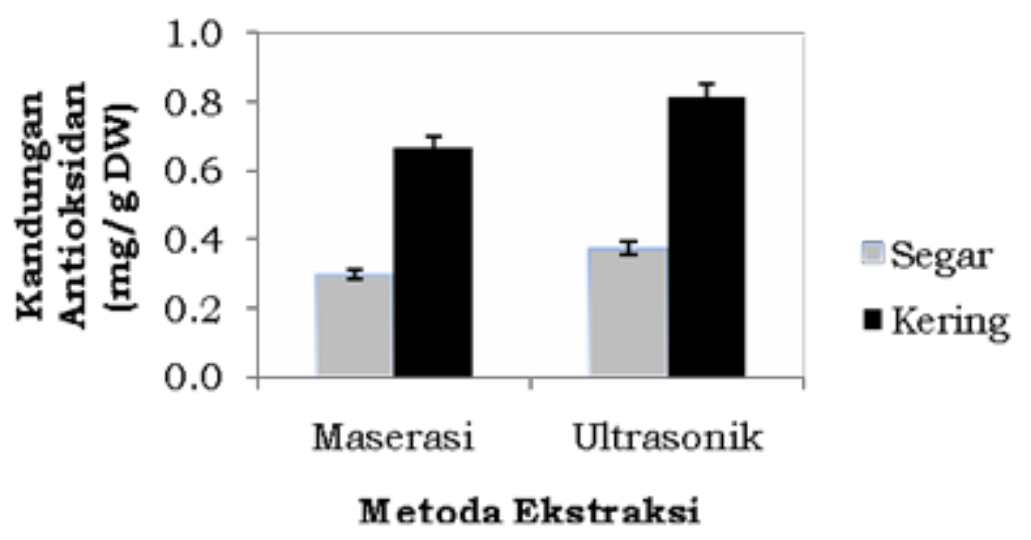

Gambar 4. Pengaruh metode ekstraksi menggunakan maserasi dan bantuan gelombang ultrasonik terhadap sampel segar dan kering angin dari rimpang kencur.

Berdasarkan Gambar 4 dapat diamati kandungan antioksidan tertinggi diperoleh dari metode ekstraksi menggunakan bantuan gelombang ultrasonik. Hal ini disebabkan gelombang ultrasonik akan menghasilkan gelembung kavitasi dalam larutan. Gelembung kavitasi akan terbentuk pada dinding sel sampel, sehingga menyebabkan terpecahnya dinding sel sampel dan proses ekstraksi menjadi lebih cepat. Penelitian yang dilakukan oleh Albayrak, et.al. (2017) mengenai penentuan kadungan fenolik dan aktivitas biologis dari Centaurea sp. menggunakan tiga metode ekstraksi (maserasi, sokletasi, dan ultrasonic) didapatkan hasil aktivitas antioksidan tertinggi pada metode ultrasonik.

Sampel rimpang kencur kering angin mngahasilkan kandungan antioksidan tertinggi dari kedua metode. Hal ini disebabkan karena rimpang kencur kering angin memiliki kadar air yang lebih rendah dibandingkan rimpang kencur segar (Tamam, B. 2011). Kandungan antioksidan yang dihasilkan dari rimpang kencur kering angin yang diekstraksi dengan maserasi dan bantuan gelombang ultrasonik adalah 0,6688 $\pm 0,02$ dan $0,8126 \pm 0,02 \mathrm{mg} / \mathrm{g}$ DW.

\section{Validasi Metode}

\section{Linearitas}

Uji linearitas digunakan untuk melihat kemampuan metode memberikan yang sesuai terhadap konsentrasi analit dalam sampel. Linearitas dihitung berdasarkan persamaan regresi yang diperoleh dari kurva kalibrasi larutan standar yang didapatkan. 
Parameter yang digunakan untuk menentukan linearitas adalah koefisien korelasi dan koefisien determinasi. Linearitas dari penentuan kandungan antioksidan dalam rimpang kencur yang diekstraksi dengan bantuan gelombang ultrasonik dapat dilihat pada Gambar 5. Dimana nilai koefisien korelasi dan koefisien determinasi yang didapatkan adalah -0,9984 dan 0,9969. Nilai koefisien korelasi dan koefisien determinasi yang didapatkan mendekati -1 dan -1 , hal ini menandakan metode memiliki hubungan linearitas yang baik.

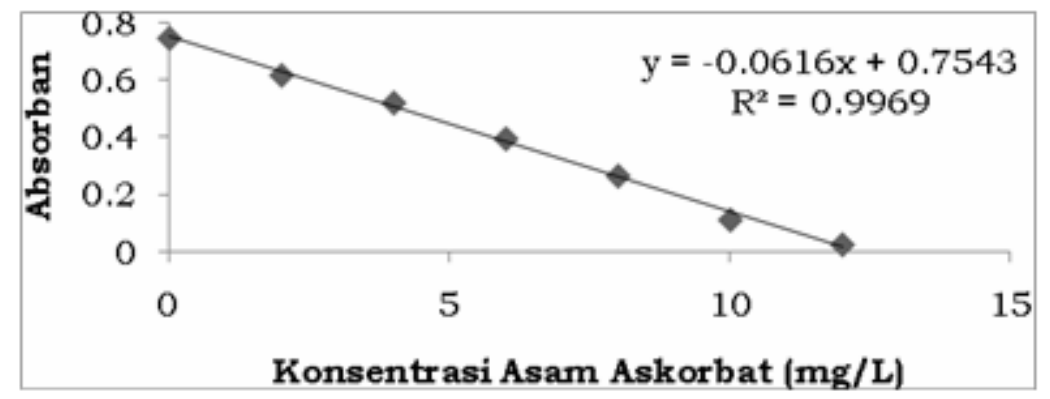

Gambar 5. Kurva Kalibarsi Larutan Standar Asam Askorbat

\section{LoD dan $L o Q$}

LoD merupakan jumlah terkecil analit dalam sampel yang masih dapat dideteksi oleh alat. Sedangankan LoQ adalah jumlah terkecil analit dalam sampel yang masih dapat dideteksi oleh alat secara kuantitatif. Semakin kecil nilai LoD dan LoQ dari suatu metode maka ketelitian dari metode tersebut semakin bagus. Nilai LoD dan LoQ yang didapat dari penentuan kandungan antioksidan dalam rimpang kencur yang diekstraski dengan bantuan gelombang ultrasonik adalah 0,0283 dan 0,0942 $\mathrm{mg} / \mathrm{L}$.

Presisi

Presisi merupakan suatu uji untuk melihat ketelitian dari suatu metode. Presisi suatu metode dilihat berdasarkan nilai SDR dan HORRAT. Menurut Association of Analytical Chemistry (AOAC) presisi suatu metode dikatakan teliti apabila memiliki nilai

,3 - 1,3. Presisi metode penentuan kandungan antioksidan yang diekstraksi dengan bantuan gelombang ultrasonik adalah $\mathrm{SDR}=1,97$ dan HORRAT $=0,96$. Berdasarkan nilai SDR dan HORRAT tersebut dapat dikatakan metode penentuan kandungan antioksidan yang diekstraksi dengan bantuan gelombang ultrasonik adalah metode yang teliti.

\section{Akurasi}

Akurasi adalah suatu uji untuk menentukan keakuratan dari suatu metode yang digunakan. Keakuratan adalah kedekatan hasil analisis dengan konsentrasi analit sebenarnya. Parameter dari penentuan akurasi adalah persen perolehan kembali. Menurut AOAC metode dapat dikatakan akurat apabila memiliki persen perolehan kembali 98-108 \%. Persen perolehan kembali dari metode penentuan kandungan antioksidan yang diekstraksi dengan bantuan gelombang ultrasonik adalah 103,21\%. 
Berdasarkan nilai persen perolehan kembali tersebut dapat dikatakan metode penentuan kandungan antioksidan yang diekstraksi dengan bantuan gelombang ultrasonik adalah metode yang teliti.

\section{KESIMPULAN}

Kondisi optimum yang diperoleh pada pengekstrasian antioksidan dalam rimpang kencur (Kaempferia galanga L.) dengan bantuan gelombang ultrasonik yaitu menggunakan $20 \mathrm{~mL}$ pelarut metanol, berat sampel $1,5 \mathrm{~g}$, dan waktu pengekstrasian 60 menit. Kandungan antioksidan yang ekstraksi dengan maserasi dan bantuan gelombang ultrasonik adalah 0,6688 $\pm 0,02 \mathrm{mg} / \mathrm{g}$ DW dan 0,8126 $\pm 0,02 \mathrm{mg} / \mathrm{g}$ DW. Berdasarkan parameter uji statistik untuk validasi metode dapat disimpulkan bahwa metode penentuan kandungan antioksdan yang diekstraksi dengan bantuan gelombang unltrasonik adalah metode yang valid untuk diterapkan.

\section{DAFTAR PUSTAKA}

Albayrak, S. Atasagun, B. Aksoy, A.: Comparison of phenolic components and biological activities of two Centaurea sp. obtained by three extraction techniques. Asian Pacific Journal of Tropical Medicine., 10(6), 599-606.

AOAC Guidelinnes for Single Laboratory Validation of Chemical Methods. 2012. USA. Bundit, T. Anothai, T. Pattaramart, P. Roongpet T and Chuleeporn, S. 2016. Comparison of Antioxidant Contents of Thai Honeys to Manuka Honey. Mal. J Nutr. 22 (3): 413-420.

Dragovic-Uzelac, V. Savic, Z, Brala, A. Levaj, B. Bursac, D. Kovacevic and Bisko, A. 2010. Evaluation of Phenolic Content and Antioxidant Capacity of Blueberry Cultivars (Vaccinium corymbosum L.) Grown in Norwthwest Croatia. Food Technology and Biotechnology., 48(2),214-221.

Elfalleh, W. Hannachi, H. Tlili, N. Yahia, Y. Nasri, N. Frechichi, A. 2012. Total phenolic contents and antioxidant activities of pomegranate peel, seed, leaf, and flower. Journal of Medicinal Plants., 6, 4724-4730.

Hadiyanto, H. Sutanto, A.A, Suharto, Y. 2014. Ultrasound assisted extraction of antioxidant from Coleus tuberosus peels. Carpathian Journal of Food Science and Technology. 6(1), 58-65.

Hayati, E.K. Ningsih, R, dan Latifah. 2015. Antioxidant activity of flavonoid frome rhizome Kaempferia galanga L. Extract. Journal of Chemistry. 4(2), 127-137.

Mathialagan, R. Mansor, N. Samsuddin, M.R, Uemura, Y and Majeed, Z. 2017. Optimisation of Ultrasonic Assisted Extraction (UAE) of Alicin from Garlic (Allium sativum L.). Chemical Engineering Transactions, 56, 1747-1752.

Muhammad, N.S. Kausar, T. Jabbar, S. Mumtaz, A. Ahad, K. Saddozai, A. Extraction and Quatification of polyphenols from kinnow (Citrus reticulate L.) peel using ultrasound and maceration techniques. Journal Food and Drug Analysis. 25, 488-500.

Petigny, L. Perino-Issatier, S. Wajsman, J and Chemat, F. 2013. Batch and Continous Ultrasound Assisted Extraction of Boldo Leaves (Peumus boldus Mol.). Molecular Sciences. 14, 5740-5764.

Salim, Z. Munadi, E. 2012. Info Komoditi Tanaman Obat. Balai Pengkajian Pengembangan Perdagangan Republik Indonesia. Jakarta.

Tamam, B. Suratiah, Dewi. N.A. 2011. Potensi ekstrak kunyit dan kencur sebagai antimikroba dan antioksidan. Jurnal Skala Husada. 8(2), 138-142. 
Suyani, N.C. Permana, D.G.M., Jambe, AA.GN.A. 2015. Pengaruh jenis pelarut terhadap kandungan antioksidanekstrak daun matoa (Pometia pinnata), Jurnal Ilmu dan Teknologi Pangan, 5(1), 1-10

Wollinger, A., Perrin, É., Chahboun, J., Jeannot, V., Touraud, D., \& Kunz, W. 2016. Antioxidant activity of hydro distillation water residues from Rosmarinus officinalis L. leaves determined by DPPH assays. Comptes Rendus Chimie, 19(6), 754-765.

Xu, D. P., Zhou, Y., Zheng, J., Li, S., Li, A. N., \& Li, H. B. 2016. Optimization of ultrasoundassisted extraction of natural antioxidants from the flower of Jatropha integerrima by response surface methodology. Molecules, 21(1), 18. 